\title{
Autosomal Dominant Disorder
}

National Cancer Institute

\section{Source}

National Cancer Institute. Autosomal Dominant Disorder. NCI Thesaurus. Code C98829.

An inherited disorder that manifests when one copy of a mutated gene is present. 